\title{
10: 61336314-61218528
}

National Cancer Institute

\section{Source}

National Cancer Institute. 10:61336314-61218528. NCI Thesaurus. Code C42114.

Physical location of D10S170 